\title{
Quantitative and qualitative observations of European sea urchin (Paracentrotus lividus, Lamarck 1816) gonad in Cesme Bay, Izmir, Turkey
}

\section{Çeşme Körfezi'ndeki Avrupa Deniz Kestanesi gonadının (Paracentrotus lividus, Lamarck 1816) kalitatif ve kantitatif incelenmesi}

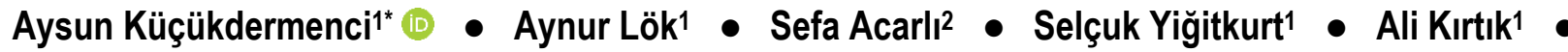 \\ Evrim Kurtay ${ }^{1}$
}

1 Ege University, Faculty of Fisheries, 35100 Bornova Izmir, Turkey

${ }^{2}$ Canakkale Onsekiz Mart University, Faculty of Fisheries, Canakkale, Turkey

*Corresponding author: aysun.kose@ege.edu.tr

Küçükdermenci, A., Lök, A., Acarli, S., Yiğitkurt, S., Kırtık, A. \& Kurtay, E. (2017). Quantitative and qualitative observations of European sea urchin

(Paracentrotus lividus, Lamarck 1816) gonad in Cesme Bay, Izmir, Turkey. Ege Journal of Fisheries and Aquatic Sciences, 34(3): 277-280.

doi:10.12714/egejfas.2017.34.3.05

\begin{abstract}
This study examined fecundity, by means of the gonad index of the most common and abundant echinoderm species (Paracentrotus lividus) of the Aegean Sea (western Turkey). Paracentrotus lividus samples were collected monthly at the coast of Cesme for six months and biometric parameters were measured and then the animals' dissected. Gonad indices were calculated. The mean fecundity (number of eggs) was determined and eggs diameter were measured. Mean egg diameter was $91.14 \pm 1.46 \mu \mathrm{m}$. There was a peak in fecundity in March (346.582 eggs/female) that correlated with the observed peak in GSI $(11.02 \pm 0.54 \%)$ and egg size $(95.68 \pm 01.98 \mu \mathrm{m})$. The results presented here show that a significant different was found in egg numbers and egg sizes between months $(p<0.05)$.
\end{abstract}

Keywords: Sea urchin, Paracentrotus lividus, gonad index, fecundity, egg size

Öz: Bu çalışmada, Ege Denizi'nde (Türkiye'nin batısı) yaygın bulunan echinoderm türlerinden Paracentrotus lividus'un fekondite ve gonad indeksi özetlenmişstir. Çeşme kıyısal alandan aylık olarak Paracentrotus lividus toplanarak biyometrik ölçümleri yapııldıtan sonra kesme işlemi gerçekleştirimiş̧tir. Gonad indeksleri hesaplanmışır. Ortalama fekondite (yumurta sayısı) belirlendi ve yumurta çapı ölçülmüştür. Ortalama yumurta çapı $91.14 \pm 1.46 \mu$ m. Fekondite Mart ayında pik yaptı (346.582 eggs/female) ve ilişkili olarak gonad indeksi $(11.02 \pm 0.54 \%)$ ve yumurta boyu da $(95.68 \pm 01.98 \mu \mathrm{m})$ bu ayda en yüksekti. Buradaki sonuçlar, aylara göre yumurta sayısı ve yumurta boyunda önemli bir farkllık $(p<0.05)$ olduğunu göstermiştir.

Anahtar kelimeler: Deniz kestanesi, Paracentrotus lividus, Gonad indeks, fekondite, yumurta boyu

\section{INTRODUCTION}

Sea urchins are known to be very reproductive (prolific) marine invertebrates, and females of some species, for example, can release as many as 100 million eggs in a single spawning period (Randall et al., 2002). Sea urchin gonad is consumed as food so gonad weight and content affect food quantity and quality (Xu and Barker, 1990). The field and laboratory studies indicate that the number of eggs produced tend to decrease when food level deteriorate (Bayne et al., 1975; Lucas and Crisp, 1987; Hirche, 1993). Gago and Luis (2010) observed that irrespectively of the broodstock stock density, mean number of eggs was always higher than $508 \pm 118 \times 10^{3}$ in $P$. lividus. Luis et al. (2005) indicated that P.lividus egg number was $788 \pm 119 \times 10^{3}$ and sea urchins emitted small and large oocytes $(\sim 65 \mu \mathrm{m}, \sim 90 \mu \mathrm{m}$ in diameter, respectively) during the maturation season. Fenaux et al. (1985) recorded average $90 \mu \mathrm{m}$ diameter in eggs of $P$. lividus.

Most life history models (McGinley et al., 1987; Roff, 1992) assume an interchange between egg size and number, i.e. females produce more, but smaller eggs in favorable environments and few, but larger eggs in unfavourable environments. Previous studies have predicted that bigger females with more resources for reproduction should produce bigger eggs and large numbers of eggs (McGindley, 1989 Sargent et al., 1987 and Venable 1992). For example, a female of $40 \mathrm{~mm}$ in diameter generally produces around 5 to 7 millions of eggs (Grosjean et al., 1998). George (1990) observed that the egg diameter of $P$. lividus (body weight was between $46 \mathrm{~g}$ 
and $71.6 \mathrm{~g}$ ) was between $89.6 \mu \mathrm{m}$ and $92 \mu \mathrm{m}$. in field studies.

Gonad indices (GSI) were changed according to species and regions, such as lower than $8 \%$ (Spirlet et al., 1998) and 6-12 \% (Spirlet et al., 2000) in Brittany, France, 4.1-5.6 \% in Algeria (Soualili and Guillou, 2009), 6 \% in Turkey (Köse, 2005).

According to most experts, aquaculture of sea urchins is the best solution for sustainablitiy of this valuable and expensive food resource with high demand whereas its natural stocks are drastically depleted due to overfishing. For sea urchin cultivation purposes, it is necessary to have an appropriate knowledge on the dynamics of the sea urchin reproduction. Our aim was to investigate the reproductive cycle of $P$. lividus in Cesme from wild, through the monthly examination of its gonad index and fecundity variations.

\section{MATERIALS AND METHODS}

Sea urchin individuals, $P$. lividus, were gathered between December 2004 to May 2005 from (038012"77'N; 026025"46'E), Cesme, Izmir (Fig 1). Sea urchin samples kept in these months in order to get gamete because Kose (2005) referred this time period for natural spawning for this populations. (Agatsuma, 1998).

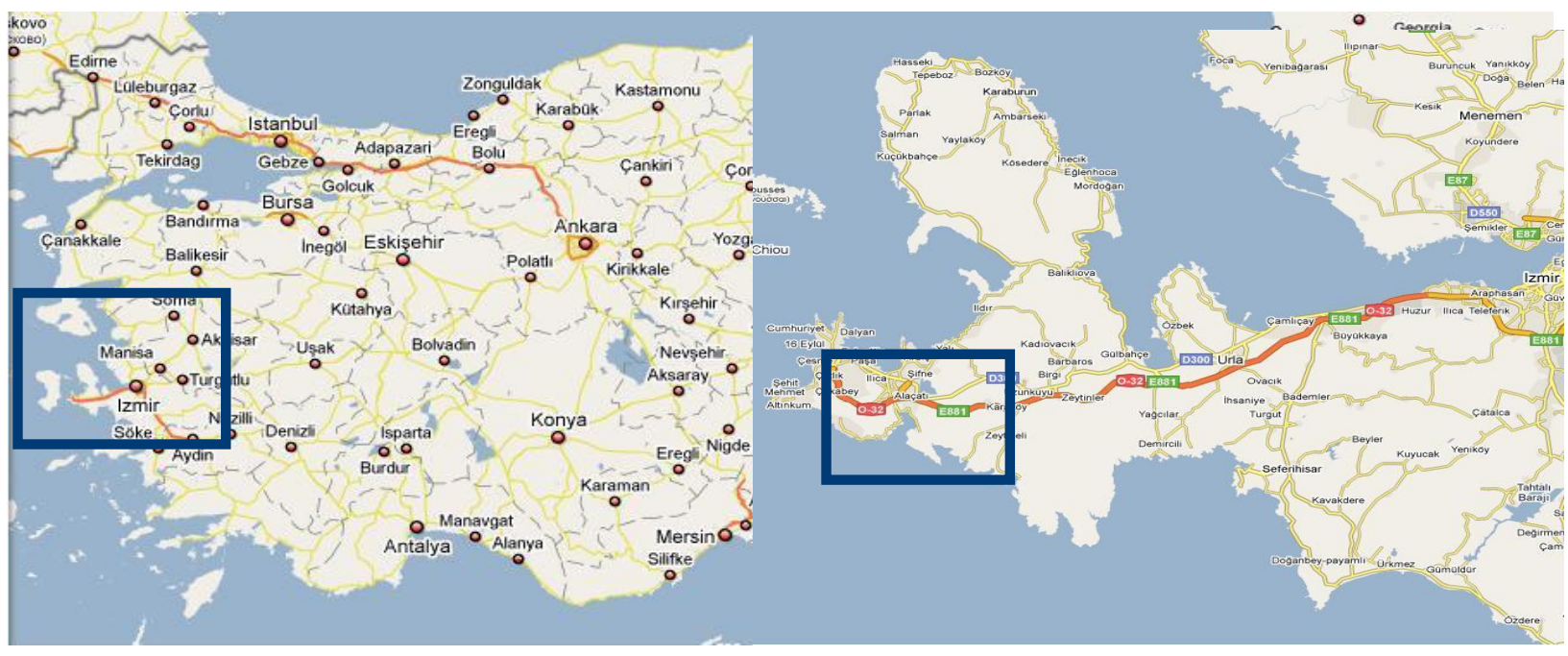

Figure 1. Geographical situation of the sampling site located in the Aegean Sea coast

On each sampling time, 30 specimens with test diameter $(19-21 \mathrm{~mm})$ were collected by hand at $0.5-1 \mathrm{~m}$ depth. The biometric measurments done were (test diameter and total weight). In addition, the surface water temperature was measured with a mercury thermometer. Following their removal, $P$. lividus samples were immediately taken to the laboratory where they were measured and dissected. Fecundity was determined by counting eggs were from each spawned females and the diameter of eggs was measured. In these samples, wet gonad index (WGI) was calculated as the ratio between the wet weight of the internal organs (WWI) and the total wet weight of the sea urchin (TWW) expressed in mg:

WGI $(\%)=($ Wet weight of gonad $/$ Total wet weight of sea urchin) $\times 100$

\section{Statistical Analysis}

Results are expressed as the mean \pm standard error. The biometric calculations and the physiological indices were made using Microsoft Excel Program. Indices of the gonad were normalized using the arcsine transformation because gonad indices are percent values. The values were subject to the analysis of Kruskal Wallis to compare indices between months. All statistical significance tests were at the $p<0.05$ levels (Watts et al., 1998).

\section{RESULTS}

The total weight of sea urchins varied between $21.34 \pm 1.09 \mathrm{~g}$ and $27.58 \pm 1.27 \mathrm{~g}$. The lowest gonad weight was measured in January and the highest was in March. The maximum egg size was measured in March $(95.68 \pm 1.98 \mu \mathrm{m})$. Mean egg size was $91.14 \pm 1.46 \mu \mathrm{m}$. A significant difference was found in egg numbers and egg sizes between months $(p<0.05)$ (Table 1).

The GSI fluctuated during the study. There was an increase from January to March then it decreased. The GSI had two peaks in March (11.02 $\pm 0.54 \%)$ and in December $(9.42 \pm 0.47)$. It was minumum in January $(2.21 \pm 0.90 \%)$. The fecundity was highest in March (346.582 eggs/female) and was lowest in January (44.000 eggs/female) (Figure 2). 
Table 1. The biometric features of Paracentrotus lividus (mean \pm SD)

\begin{tabular}{|c|c|c|c|c|c|c|}
\hline & $\begin{array}{ll}\begin{array}{l}\text { Diamaeter } \\
(\mathrm{mm})\end{array} & \mathbf{\pm S D} \\
\end{array}$ & $\begin{array}{l}\text { Total weight } \pm \text { SD } \\
\text { (g) }\end{array}$ & $\begin{array}{l}\text { Gonad weight } \pm \text { SD } \\
\text { (g) }\end{array}$ & $\begin{array}{l}\text { Gonad index } \pm S D \\
(\%)\end{array}$ & Eggs number $\pm \mathrm{SE}$ & $\begin{array}{lll}\begin{array}{l}\text { Eggs } \\
(\mu \mathrm{m})\end{array} & \text { size } & \pm \mathrm{SD} \\
\end{array}$ \\
\hline Dec & $20.35 \pm 1.11$ & $24.19 \pm 2.11$ & $2.28 \pm 0.12$ & $9.42 \pm 0.47$ & $44.000 \pm 13.245$ & $91.20 \pm 0.87$ \\
\hline Jan & $21.90 \pm 0.96$ & $27.58 \pm 1.27$ & $0.61 \pm 0.13$ & $2.21 \pm 0.90$ & $36.581 \pm 9.589$ & $89.60 \pm 0.69$ \\
\hline Feb & $19.50 \pm 0.85$ & $21.34 \pm 1.09$ & $0.94 \pm 0.10$ & $4.40 \pm 0.72$ & $203.615 \pm 57.928$ & $94.98 \pm 1.45$ \\
\hline March & $19.20 \pm 1.66$ & $22.68 \pm 2.82$ & $2.50 \pm 0.15$ & $11.02 \pm 0.54$ & $346.582 \pm 61.074$ & $95.68 \pm 1.98$ \\
\hline April & $19.70 \pm 1.05$ & $22.90 \pm 1.78$ & $1.75 \pm 0.18$ & $7.64 \pm 0.63$ & $111.125 \pm 39.064$ & $86.24 \pm 0.50$ \\
\hline May & $19.60 \pm 1.95$ & $22.70 \pm 0.04$ & $1.50 \pm 0.83$ & $6.60 \pm 1.57$ & $153.649 \pm 59.729$ & $89.25 \pm 1.37$ \\
\hline Total & $20.00 \pm 0.41$ & $23.56 \pm 0.88$ & $1.59 \pm 0.30$ & $6.88 \pm 1.28$ & $149.256 \pm 47.303$ & $91.14 \pm 1.46$ \\
\hline
\end{tabular}

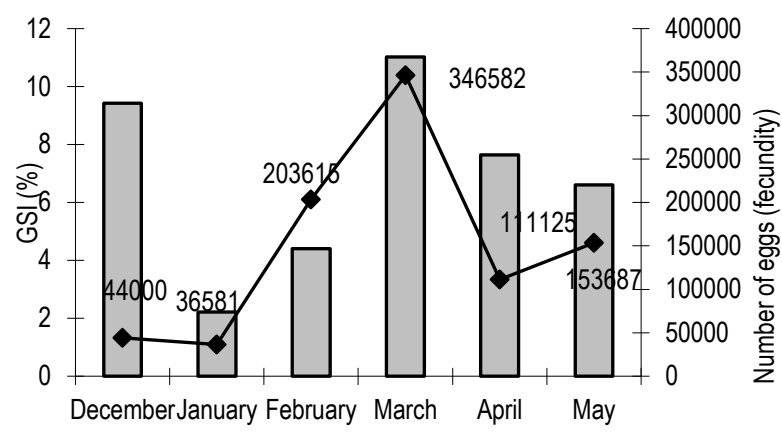

Figure 2. Time course of the gonadosomatic index and number of eggs in sea urchins during the study period

The surface water temperature at the sampling site did some variation within months. It ranged from $14^{\circ} \mathrm{C}$ to $19^{\circ} \mathrm{C}$. The water salinity was stable (36\%) during the study (Figure 3).

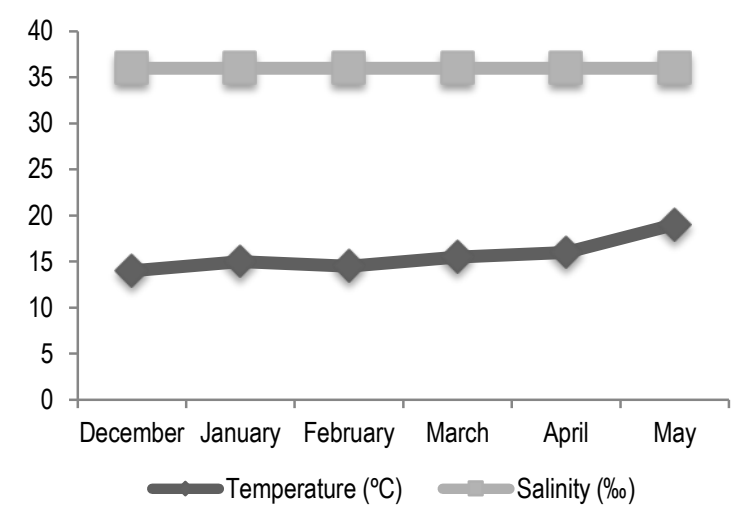

Figure 3. Variations temperature and salinity monthly

\section{DISCUSSION}

Egg size and number varies within and among females at a site and between sites (Emlet et al., 1987). Luis et al. (2005) indicated that wild P.lividus egg number was $788 \pm 119 \times 10^{3}$ in Portugal. Gago and Luis, (2011) obtained that $P$. lividus female spawning was between $23 \pm 10 \times 10^{3}$ and $178 \pm 59 \times 10^{3}$ with different mechanical shock techniques. In this study, egg numbers were higher $\left(36.58 \pm 9.58 \times 10^{3}\right.$ and $346.582 \pm 61.07 \times 10^{3}$ ) than Gago and Luis (2011). Several factors such as temperature, photoperiod, dietary resources availability and water turbulence are pointed out as controlling gametogenesis of wild $P$. lividus populations (Fenaux, 1968) but taking spawning into account the main environmental trigger is not clearly known (Lopez et al., 1998). Fenaux (1968) indicated temperature as the main trigger of spawning episodes in field populations of Paracentrotus lividus, but this effect was not detected in present study because the temperature was not significiantly different during the study. The differences in egg size or number observed in field studies might be due to differences in the abundance of preffered algae at the different sites. The field and laboratory studies indicate that the number of eggs produced tend to decrease when food conditions deteriorate (Bayne et al., 1975; Lucas and Crisp, 1987; Hirche, 1993). Morris (1992) predicted that adult and offspring survival might not be independent of environmental conditions, but increase as environmental conditions improve and decrease as environmental conditions deteriorate (McGinley et al., 1987).

Grosjean et al. (1998) observed that a female of $40 \mathrm{~mm}$ in diameter produces around 5 to 7 millions of eggs. In the current study sea urchin individuals were smaller $(19-21 \mathrm{~mm})$ and number of eggs were fewer $\left(149 \times 10^{3}\right)$ than the Grosjean et al. (1998) study. The present results are in agreement with Begon and Parker (1986) who predicted that bigger females should produce bigger eggs and a larger number of eggs. George (1990) observed that egg diameter of $P$. lividus (body weight $58.8 \mathrm{~g}$ ) was $90.8 \mu \mathrm{m}$. in field studies. In the current study, body weight was lower $(24.9 \mathrm{~g})$, egg diameter was higher $(92.4 \mu \mathrm{m}$.) than in the George (1990) study. These differences might be down food which influences both somatic growth and reproductive condition in sea urchins (Beddingfield and McClin tock, 1998).

Gonadosomatic index of $P$. lividus in natural condition ranges between $6 \%$ and $12 \%$ (Spirlet et al., 2000). Luis et al. (2005) referred to pooled data for captive fed urchins and showed that $49.0 \pm 0.55 \mathrm{~mm}$ and $31.3 \pm 0.8 \mathrm{~g}$ individuals had $10.5 \%$ gonad index. In the present study, $20.00 \pm 0.41 \mathrm{~mm}$. and $23.56 \pm 0.88 \mathrm{~g}$. P. lividus had a GSI of $6.8 \%$. The variations in body size and gonadosomatic index of sea urchins could be related to quantity and quality of feed. The algal community in the area of study is consist of only Posidonia sp. and a little 
macralgae such as Padina sp. Therefore it could be reason for a low GSI.

Fenaux (1968) Paracentrotus lividus egg diameter was 90 $\mu \mathrm{m}$ assimiliar to Luis et al., (2005). In present study, mean egg size $(91.14 \pm 1.46 \mu \mathrm{m})$ was close the values of other studies (George, 1990; Fenaux, 1968). The egg size and content increases irrespective of mode of development when environmental conditions improve (George, 1996). In most of individuals examined, egg size remained constant and in a few cases decreased when food conditions deteriorated (George,

\section{REFERENCES}

Agatsuma, Y. (1998). Aquaculture of the sea urchin (Strongylocentrotus nudus) transplanted from coralline flats in Hokkaido, Japan. Journal of Shellfish Research, 17(5): 1541-1547.

Bayne, B.L., Gabbott, P.A. \& Widdows, J., (1975). Sorne effects of stress in the adult on the eggs and larvae of Mytilus edulis (L.). Journal of the Marine Biological Association of the United Kingdom, 55: 675-689.

Beddingfield, S.D. \& McClintock, J.B. (1998). Differential survivorship reproduction, growth and nutrient allocation in the regular echinoid Lytechinus variegates (Lamarck) fed natural diets. Journal of Experimental Marine Biology and Ecology, 226(2): 195-215.

Begon, M. \& Parker, G. A. (1986). Should egg size and clutch size decrease with age? OIKOS 47: 293-382.

Emlet, R.B., McEdward, I. R., \& Strathmann, R.R. (1987). Echinoderm larval ecology viewed from the egg. Echinoderm Studies. 2: 55-136.

Fenaux, L. (1968). Maturation des gonades te cycle Saisonnier des larves chez Arbacia lixula, Paracentrotus lividus et $P$. microtuberculatus (Echinides) a Villefranche-sar-Mer. Vie Milieu, 19:1-52.

Fenaux, L., Cellario, C. \& Etienne, M. (1985). Croissance de la larve de l'oursin Paracentrotus lividus. Marine Biology 86: 151-157.

Gago, J. \& Luis, O.J. (2010). Stocking density and captive sea urchin Paracentrotus lividus (Lamarck, 1816) gamete production and fertilization (Report). Journal of Shellfish Research. doi: 10.2983/035.029.0230

Gago, J. \& Luis, O.J. (2011). Comparison of spawning induction techniques on Paracentrotus lividus (Echinodermata: Echonidea) broodstock. What can trigger its spawning? Aquaculture International. 19: 181-191. doi: 10.1111/j.1365-2109.2009.02467.x

George, S.B., Cellario, C. \& Fenaux, L. (1990). Population differences in egg quality of Arbacia lixula (Echinodermata: echinoidea): Proximate composition of eggs and larval development. Journal of Experimental Marine Biololgy and Ecology. 141: 107-118.

George, S.B. (1996). Echinoderm egg and larval quality as a function of adult nutritional state. Oceanologica Acta. Vol: 19 (3-4): 297-308.

Giese, A.C. (1966). On the biochemical constitution of some echinoderms. In: R.A. Boolootion ed. Physiology of Echinodermata. New York., Wiley.

Grosjean, P.H., Spirlet, C.H., Gasselin, P., Vaitilingon, D. \& Jangoux, M. (1998) Land-based closed cycle echinoculture of. Paracentrotus lividus a longterm experiment at a pilot scale. Journal of Shellfish Research. 17(5): 1523-1531.

Hirche, H. J. \& Kattner, G. (1993). Egg production and lipid content of Calanus glacialis in spring: indication of a food-dependent and foodindependent reproductive mode. Marine Biology. 117: 615-622

Köse, A. (2005). A study about the gonad productivity and the indices changes of sea urchin (Paracentrotus lividus Lamarck, 1816) These Doct. Ege University. Department of Aquaculture.

López, S., Turon, X., Montero, E., Palacín, C., Duarte, C.M. \& Tarjuelo, I. (1998). Larval abundance, recruitment and early mortality in
1996). In current study, we observed that the egg size and number were higher in February and March. In these months, sea urchins might live favourable conditions such as food and water or might be spawning season.

Aquaculture of sea urchins is the best solution for sustainability of this valuable and expensive food resource with high demand whereas its natural stocks are drastically depleted due to overfishing. Therefore these conclusions can be used to develop increasing sea urchin aquaculture for human consumption.

Paracentrotus lividus (Echinoidea). Interannual variability and planktonbenthos coupling. Marine Ecology Progress Series 172: 239-251.

Lucas, M.I. \& Crisp, D.J. (1987). Energy metabolism of eggs during embryogenesis in Balanus balanoides. Journal of the Marine Biological Association of the United Kingdom. 61: 27-54.

Luis, O., Delgado F. \& Gago. J. (2005). Year-round captive spawning performance of the sea urchin Paracentrotus lividus: relevance for the use of its larvae as live feed. Aquating Living Resource 18: 45-54. doi: $10.1051 / 2005004$

McGinley, M.A., Temme, D.H. \& Geber, M.A. (1987). Parental investment in offspring in variable environments: Theoretical and empirical considerations. The American Naturalist 130: 370-398.

McGinley, M.A. (1989). The influence of a positive correlation between clutch size and offspring fitness on the optimal offspring size. Evololution Ecology 3, 150-156.

Morris, D.W. (1992). Optimum brood size: Tests of altemate hypotheses. Evolution 46, 1848-1861.

Randall, D., Burggren,W. \& French. K. (2002). Eckert Animal Physiology: Mechanisms and Adaptations. 5th edition. W. H. Freeman and Company, New York, USA.

Roff, T D.A. (1992). The evolution of li fe histories. Theory and anal ysis. Chapman and Hall, New York. $535 p$

Sargent, R.C., Taylor, P.D. \& Gross, M.R. (1987). Parental care and the evolution of egg size in fishes. The American Naturalist 129, 32-46.

Soualili, D. \& Guillou, M. (2009). Variations in the reproductive cycle of the sea urchin Paracentrotus lividus in three differently polluted locations near Algiers (Algeria). Marine Biological Association of the United Kingdom. Vol: 2. doi: 10.1017/S175526720900092X

Spirlet, C., Grosjean, P., \& Jangoux, M. (1998). Reproductive cycle of echinoid Paracentrotus lividus: analysis by means of the maturity index. Invertebrate Reproductian and Development, 34: 1-69-81 Daleban, Philadelphia.

Spirlet, C., Grosjean, P. \& Jangoux, M. (2000). Optimization of gonad growth by manipulation of temperature and photoperiod in cultivated sea urchins, Paracentrotus lividus (Lamarck) (Echinodermata). Aquaculture, 185: 8599.

Venable, D.L. (1992). Size-number trade-offs and the variation of seed size with plant resource status. The American Naturalist. 140: 287-304.

Watts, S.A., Boettger, S.A., McClintock, J.B., \& Lawrence, J.M. (1998). Gonad production in the sea urchin Lytechinus variegatus (Lamarck) fed prepared diets. Journal Shellfish Research 17: 1591-1595.

Xu, R.A. \& Barker, M.F. (1990). Photoperiodic regulation of oogenesis in the starfish Sclerasterias mollis (Hutton 1872) (Echinodermata: Asteroidea). Journal of Experimantal Marine Biology and Ecology. Vol: 141: 2-3. Pages: 159-168. doi: 10.1016/0022-0981(90) 90221-W 